\title{
REDEFINING HOME AND HOMELESSNESS IN MARILYNNE ROBINSON'S LILA
}

Ksenija Kondali, University of Sarajevo, ksenija.kondali@ff.unsa.ba

Original scientific paper

DOI: $10.31902 /$ fll.36.2021.3

\begin{abstract}
The recent decades have brought an intensified reconsideration of home, its concept, values, and importance, investigated not only as an actual physical space but also as a representational space and a place in memory. Contemporary scholarship has increasingly approached the domestic space as socially constructed, representing power negotiation and contestation. Drawing on concepts from cultural and feminist geographers, this paper seeks to interrogate Marilynne Robinson's novel Lila and its understanding of belonging and isolation while questioning the concept of home. The purpose of this paper is to illustrate how the gendered place of home is renegotiated in this novel that revises concepts of femininity as its protagonist struggles with adapting to a life of domestic dynamic in the heartland of America, which Robinson prefers to call "the middle west". In other words, this paper establishes the relevance of approaching the novel's representation of home and homelessness as a spatial study with a gender lens. ${ }^{1}$
\end{abstract}

Keywords: American novel, domestic womanhood, homelessness, sense of place, belonging, gender relations, female subjectivity

\section{Introduction}

This paper engages home and the loss or lack of it through the findings of cultural and feminist geographers to interrogate Marilynne Robinson's novel Lila, and, more specifically, on home, belonging, vagrancy, exclusion, and isolation. When Robinson's latest and fourth novel Lila was published in 2014, most critical and popular opinion hailed it as the third of the Gilead trilogy since it is set in an eponymous midwestern town, like her two previous ones - Gilead (2004) and Home

${ }^{1}$ An earlier version of this article was presented at the XV International Conference on Anglo-American Literary Studies, "Home-Thoughts, from Abroad" organized by the Department of English Language and Literature, Faculty of Philology, University of Montenegro, in Cetinje, Montenegro, June 27-28, 2019. 
$(2008)^{2}$. Although this novel centers on the relationship between Lila and the Reverend John Ames, it also offers flashbacks to Lila's girlhood on the margins of society, of a life of fear, want, and longing. All the Gilead novels, including Robinson's first novel Housekeeping, are infused with references to loneliness, the heroines' and that of the other characters, because most of them, such as the title character of Lila, are on a quest for a home and identity. In the words of a critic, this novel revisits "the themes of alienation and separateness (and the possibility of belonging) that animated her astonishing debut novel, Housekeeping, more than 30 years ago" (Kakutani 1). But Lila also offers other staple elements of Robinson's work, most of them bound to identity formation, nature, faith, and memory. Ever since Robinson's debut novel in 1980, critical attention has alerted to the author's preoccupation with faith and modern disaffection. In his review of the novel, largely devoted to the issue of religion in Robinson's oeuvre and its immanence in Lila, Colm Tóibín notes that the novelist "deals with hunger and violence and carnality, but she also wishes to dramatise religious questions" (23). Another reviewer, Joan Acocella, who evaluates the novel as "an unflinching book", admires the point-of-view narration, employed to underscore the characters' vision and sense of self: "because they don't see the same reality, they are consigned to solitude" (n.p.). But this article moves away from a textual analysis of Robinson's narrative strategies and directs its critical examination to the experience of home and womanhood as challenged by the protagonist's renegotiation of place and sense of belonging. To that end, an outline of several main approaches to the spatiality of home is offered in the next section as an introduction to the proposed analysis of the novel.

\section{Home: A Gendered Place}

In times of surging migration and overall individual vulnerability, the centrality of home and belonging looms large in popular and critical perception. The prevailing concepts of home signify belonging, intimacy, and a sense of place and self, but they also invoke a range of other interpretations and implications, principally those concerning space, culture, and identity. Since the 1970s, the consideration of the domestic space in the field of geography has resulted in new research across the humanities and social sciences, rooted in humanistic geographers' investigations, and unsettling previous positivist and abstract spatial notions. Early theorizations of spatiality were phenomenological

\footnotetext{
${ }^{2}$ For Rachel Sykes, the latest two novels by Robinson, Home and Lila, are paired together, as "two partner novels" (2018: 425).
} 
interpretations by Gaston Bachelard in his study The Poetics of Space. Establishing that the primary response of people to space, dwelling and home is crucial in the development of their sense of themselves related to a place of wellbeing and rootedness, he proposes that "our house is our corner of the world" (Bachelard 4) and exalts home as being "our first universe" (Ibid.). For Bachelard, a house is manifestly a permanent construction which is conducive as a shelter but also as a retreat, with the capacity to fulfill the fundamental human needs of peace, nurture, comfort, intimacy, and solitude, so it allows us to "dream in peace" (Bachelard 6). Following his reasoning, home is the locus decisively vested with our beginnings, departures and returns, a place individuals claim and make their own, infused with the feeling of self and hope. Bachelard's studies have served as an inspiration to other authors in spatial studies, including Edward Relph, who also maintains the primacy of the home in our lives as "the most central reference point of human existence" and "an irreplaceable centre of significance" $(20,39)$. Infused with a nostalgic afterglow of remembrances of events and people that impart an affectionate connection to a particular place, Relph contends that home is "the foundation of our identity as individuals and as members of a community, the dwelling-place of being" (Relph 39). It is evident that these ideas of home approach it not only as an actual physical space but also as a representational space and a place in memory.

At the same time, these phenomenological notions of our intense and sensual attachment to a place, and of home as a personal, intimate, and poetical place have overlook important categories of power dynamics and categories of gender, class and race. The ideological construction of home as peaceful, welcoming, and safe has established the domestic space as the central site of success in the American understanding of progress and self-realization. To have a stable home has been constructed as instrumental to the feeling of normalcy, achievement, and the sense of self. A critical re-evaluation of home in contemporary scholarship has challenged the ideal home according to Bachelard, for whom the domestic space is peaceful and nurturing while "the outside has no more meaning" (85). In contrast to these views, recent research has recognized the importance of external influences upon the dynamics of home as socially constructed, representing power negotiation and resistance. Evidently abstract, Bachelard's theorization of home elides the voices of others, particularly women, who inhabit the space. These understandings of home, particularly of its contradictory nature, has been more widely recognized in recent feminist studies, aiming to contest and debunk the masculine account of autonomy and 
power structures. Humanistic geographers have neglected the fact that "[c]oncepts of place and space are implicitly gendered in geographical discourse", according to Gillian Rose (56). Failing to recognize the workings of power relations of difference and inequality, home is reduced to a place of safety, support and care exclusively, eliding the potential of opposite experiences. Under the influence of feminist and other theories, cultural geographers have examined the contested aspects of home that have been often associated with the politics of location and identity. These studies have analyzed the ways in which topographies of home are shaped by difference, not only in terms of gender but also race, class, and sexuality.

In the deconstruction of these man-centered and gendered projections of place generally, and home specifically, traditional approaches to the study of these spatial categories were scrutinized, especially in gender studies of space. In her book Gender, Identity and Place Understanding Feminist Geographies, Linda McDowell warns of the complexity and importance of investigating domestic space, particularly to " $\mathrm{t}]$ he meaning of the home, the nature of a house and the consequences of homelessness across space and time in different societies and regions" (93). Intent on avoiding an essentialist approach to spatial issues, feminist politics must reenvisage both space and gender as "a network of relations, unbounded and unstable" (McDowell 36). Through these critical lenses, domestic sites are reevaluated from a new vantage point, in defiance of the previously dominant and entrenched views. As McDowell contends: "And although the house and the home is one of the most strongly gendered spatial locations, it is important not to take the associations for granted, nor to see them as permanent and unchanging" (93).

Another prominent author in the field of feminist geography, Doreen Massey, notes in her study, Space, Place, and Gender, that in academic study as well as wider culture there has been a propensity to the idea of place as "bounded, as in various ways a site of authenticity, as singular, fixed and unproblematic in its identity" (4). Massey suggests that limits placed on the mobility of space, the confinement of particular places as bounded and static, have played a role in defining the mobility of identity. She contends that while time and history have been traditionally regarded as dynamic, as becoming, and thus coded masculine, space has been viewed as static, as being, as absence or lack, all of which are coded feminine (Massey 6). Evidently, the conceptualization of space as the absence of the dynamic, containing both space itself and women, intersects in the home, or, in Massey's view: "the identity of 'woman' and of the 'home-place' are intimately 
tied up with each other" (180). As a long-standing symbol of stability and self-realization, home for Massey is the site of a physical, geographical or architectural construction as well as identity formation (151). As a space of belonging, alienation, intimacy, violence, desire, and fear, home is charged with meanings, emotions, experiences, and relationships that lie at the heart of human life, which she terms a "place-called-home" (Ibid.). However, conversely, for those who have no place that can be safely called home, there must be a struggle for a place to be. To have no "place-called-home" goes against the customary codification of domestic space for women: "Homelessness for women challenges every assumption about a woman's place [...]" (McDowell 90). The exploration of home and the topics related to it has therefore been increasingly centered on its meaning as a site of inclusion, exclusion and contestation, but also on the importance of home, and particularly the roles of women within it, in shaping memories and identities. The intersection of the physical and the sensorial aspects of home in contemporary scholarship differs from Bachelard's idealization of home, as exemplified by Alison Blunt and Robyn Dowling, who have developed a critical geography of home. In their study Home (2006), they explicate their approach to home as involving three main intertwined constituents: "home as material and imaginative; the nexus between home, power and identity; and the multi-scalarity of home" (254). Affirming that "[h]ome is much more than a house or the physical structure in which we dwell. Home is both a place or physical location and a set of feelings" (254), Blunt and Dowling suggest that the material and imaginative geographies of home are fully interlaced. Home is a connection between the material and imaginative spheres and practices, with the physical locus, perceptions and feelings linking and shaping each other. Consequently, home is a development of both inhabiting such a space and making sense of belonging to it. Recent scholarship also calls attention to the nexus of home, power and identity and how they are intimately linked:

Home as a place and as a spatial imaginary helps to constitute identity, whereby people's senses of themselves are related to and produced through lived and metaphorical experiences of home. These identities and homes are, in turn, produced and articulated through relations of power (Blunt and Dowling 256).

Such arguments demonstrate that home is no longer understood in terms of a static and restricted location that is the foundation and site of identity. Home and identity manifest how they are mutually grounded and relate to each other. 


\section{Home: Lost and Found in Gilead?}

Robinson, whom a New York Times critic calls the "moralist of the midwest" (O'Rourke 63) acknowledges her strong affiliation to that region also in the dedication of Lila. It reads "To lowa", which Alex Engebretson appropriately calls Robinson's "literary home, her very own Yoknatatawpha County" (78), that has rendered to her oeuvre "a quality of roundness and continuity" (79). In addition to the setting, unity is achieved through various elements of style, character, thoughts, and mood, but also thanks to a shared concern in Robinson's work with the sense of place, drawing the conclusion that "much of her writing explores particularly female spaces, places, and times" (Mariotti and Lane, Jr. 9). While Lila revisits the setting and characters Robinson's Gilead and Home, its homeless protagonist also recalls the ending of her first novel, Housekeeping, in when its heroine Ruth opts to leave her hometown and adopt a life of drifting. In the novel Lila, the eponymous heroine was an abandoned and neglected toddler until her liberation by a transient young woman named Doll. Lila grows up under her care in a group of itinerant workers and the two shape a life on the run, living hand to mouth. One day, after years of roaming the countryside, living a hardscrabble life, Lila steps inside a small-town Congregationalist church in Gilead, lowa, to shelter from the rain, and there she meets the local reverend John Ames. A romance develops between them and they get married, but while Lila embarks on a new life of household routine and a safe environment, she tries to make sense of her past and the various constructions of "home".

While Lila and Ruth, as the main characters of Lila and Housekeeping respectively, are both transients a good part of their lives, they are substantially different since Lila has no actual domestic location and no immediate kin, unlike Ruth and her aunt who have a family house but end up burning it. As such, Lila takes a different road to Ruth as she "comes to terms with her vagrant and sometimes criminal past, converts to Christianity, and struggles to make Gilead her physical and spiritual home" (Sykes 2019: 429) ${ }^{3}$. While the pursuit of home in Lila comes in the form of a narrative that speaks of striving for domestic peace and

${ }^{3}$ This novel is analyzed by Rachel Sacks in her recent study The Quiet Contemporary American Novel, which specifies "quiet as an aesthetic of narrative that is driven by reflective principles and places Robinson within a vibrant contemporary American trend" (2018: 1). Correspondingly, such classification might also be apposite for Robinson's novels Gilead and Home, but others, too, for instance, Paul Harding's Tinkers and Elizabeth Strout's Olive Kitteridge. 
contentment, the story also brings images that impart the sense of displacement, making us question the normative ideas of home. Given the importance of the domestic space and the private realm of family life in Marilynne Robinson's fiction, it hardly comes as a surprise that she has been labeled a "domestic novelist". But, as Alex Engebretson (12) warns, such pigeon-holing of this writer is reductive and "does not capture the visionary qualities Robinson finds in the domestic. [...] On a metaphysical level, each of the novels assumes that at the center of every human is the need for home." In Lila, there is an engagement of the domestic space from a less common perspective, with a distinctly female focalization, that speaks of an "evident shift to the female rather than male-centredness initiated in Home but even more explicitly portrayed in Robinson's latest novel, giving rise to the conclusion that this is "a return to origins'" (Engebretson 79). In a similar vein, both novels oppose the customary understanding of home as a private, free, safe, and secure place and present how patriarchal pressure may be countered as domestic destruction and liminal spaces.

The quest for a home is a burdensome process for Robinson's heroines, including Lila, who is grouped with "her most vivid characters [...], all of whom are outsiders, strangers, exiles who are forced to negotiate the tensions of a newfound domesticity" (Engebretson 12). Robinson's novels tend to revolve around finding a place of belonging, a place that can be "home", that represents both a site and an idea, imbued with meaning for the largely hapless heroes and heroines of her fiction. Following Shannon Mariotti's argumentation about "home" representing the ideological space of settled conventions, firm foundations, comfort, and certainty, the main characters in Robinson's novels, who are outsiders, homeless strangers, "take on an air of homelessness all the while never fully leaving the more familiar places and spaces of home" (Mariotti 24). Lila has no deep attachment to a single, clearly specified place or home area and therefore no sense of continuity or enduring relationship with a place to call home, even when she settles in Gilead as the Reverend's wife. Her long years of growing up displaced and deprived have marked Lila, and this experience affects her sense of self and the understanding of feeling at home. Lila is introduced to the readers as a toddler, abandoned on the front porch of what seems a boardinghouse or workhouse, suffering from the elements, hunger, and despair. The novel's opening sentences poignantly depict the misery of the domestic scene as an ironic recasting of home as "natural shelter":

The child was just there on the stoop in the dark, hugging herself against the cold, all cried out and nearly sleeping. She couldn't holler 
anymore and they didn't hear her anyway, or they might and that would make things worse. Somebody had shouted, Shut that thing up or I'll do it! and then a woman grabbed her out from under the table by her arm and pushed her out onto the stoop and shut the door and the cats went under the house. They wouldn't let her near them anymore because she picked them up by their tails sometimes. Her arms were all over scratches, and the scratches stung. She had crawled under the house to find the cats, but even when she did catch one in her hands it struggled harder the harder she held on to it and it bit her, so she let it go. Why you keep pounding at the screen door? Nobody gonna want you around if you act like that. And then the door closed again, and after a while night came. The people inside fought themselves quiet, and it was night for a long time. (Robinson 3)

The violent and striking opening of the novel captures the liminality of the stoop as a border between the outcast state and the unwelcoming inside of the dwelling, which is far from the place of repose cast by Bachelard's house that enables "dreaming in peace" (cf. 1994: 6). There is no atmosphere of safety around this house, even though it may be the child's "first universe" (cf. Bachelard). The synecdoche of the described human interaction indicates the opposite: there are just voices, unidentified, "expressing exclusion and dehumanized hate [...] These truly hellish conditions leave the reader little room to believe that Lila would be better off staying" (Engebretson 83). These early traumatic childhood experiences instill in Lila a sense of multiple deprivations: of shelter, trust, nurture, and with a feeling of loss, marking her for life in interpersonal dynamics. In the words of a critic: "This sense of rootlessness and dislocation will stay with Lila, making her skittish and wary, a wild child, afraid of belonging to anyone or caring too much" (Kakutani 1). But clearly, Lila was saved by Doll, who had tried to attend to Lila before she took the child away with her in a desperate effort to make up for the dismal life in that house with little acts of kindness, looking after her as much as she could:

When the child stayed under the table, they would forget her most of the time. The table was shoved into a corner and they wouldn't go to the trouble of reaching under to pull her out of there if she kept quiet enough. When Doll came in at night she would kneel down and spread that shawl over her, but then she left again so early in the morning that the child would feel the shawl slip off and she'd feel colder for the lost warmth of it, and stir, and cuss a little. But there would be hardtack, an apple, something, and a cup of water left there for her when she woke up. Once, there was a kind of toy. It was just a horse chestnut with a bit 
of cloth over it, tied with a string, and two knots at the sides and two at the bottom, like hands and feet.

The child whispered to it and slept with it under her shirt. (Robinson 4)

This scene signals the loneliness and yearning for a domestic space that constitutes a "place-called-home" (cf. Massey) while initiating the themes of home, belonging, and intimacy. In her recollection later as a grown woman, Lila connects the workhouse with being outcast, wary and miserable, and deems Doll her savior:

Doll had taken her up in her arms and wrapped her shawl around her. "You just hush now," she said. "Don't go waking folks up." She settled the child on her hip and carried her into the dark house, stepping as carefully and quietly as she could, and found the bundle she kept in her corner, and then they went out into the chilly dark again, down the steps. The house was rank with sleep and the night was windy, full of tree sounds. The moon was gone and there was rain, so fine then it was only a tingle on the skin. (Robinson 4-5)

To Lila, Doll seems like "an angel in the wilderness" (Robinson 30), but these passages also introduce the wild that Lila embraces - as a child in the shape of the gifted horse chestnut as a makeshift toy, in her sensory alertness to natural elements, then as a lonely drifter, through the hut outside Gilead and even later in her life, when she marries John Ames. After she becomes Mrs. Ames, she still clings to Doll as a role model and evaluates her current domestic arrangement against her past experiences: "[...] she just imagined how all of it would seem to Doll-a very good life, a comfortable life that she had because Doll had stolen her, and had taken care of her all those years. She lived for Doll to see" (Robinson 97). Soon after Doll takes Lila, they join a small group of itinerant farmhands. But within this band, they are not fully accepted, and this feeling of marginality is amplified by their homelessness and precarious existence. An important stage in Lila's quest for "home" is the year she and Doll spent in Tammany, lowa, when Lila went to school and experienced "a real house" (Robinson 41) for the first time. The following passage reveals how the domestic space - even if just a temporary collective abode - is problematic and serves as an ambivalent element in the process of grasping notions of belonging and marginality:

A respectable boardinghouse in the town of Tammany, lowa. Doll took a job there so Lila could go to school for a year, long enough to learn how to read and do some figures. Mrs. Marker, whose house it was, did the cooking, but Doll did the cleaning and laundry and looked after the poultry and the gardens, and Lila helped with all of it. Doll wanted her to know what it was to have a regular life. Not that Doll knew 
much about it herself, but Mrs. Marker would yell about everything she did wrong, so she got better at it with time, until school was almost out.

Lila liked school. She liked sheets and pillowcases. They had a room of their own, with curtains and a dresser. They ate their supper at a table in the kitchen, where Lila did her lessons while Doll washed the dishes. Doll never did complain, so Lila was surprised when she said they were going to leave, but she didn't say a word and she didn't look back, though the house had seemed pretty to her. It was where she had learned to tend roses. (Robinson 42)

The household routine, material comfort, and education opportunity define Lila's sense of home, but they do not bend her loyalty to Doll, underlying the notion that intimacy is the key to developing a sense of belonging in a space, not the actual locus itself. The detail of learning to take care of something (in this case, roses) affects Lila's identity construction and represents the habit of domestic life she continues when she arrives in Gilead and tends to the roses on the grave of Ames' first wife. Almost embarrassed, she seems to make excuses to herself for doing more gardening, signifying the process of taking roots in town: "When she came there at first to tend the roses and clean things up, she had made a little garden in a corner and planted a few potatoes, just for herself" (Robinson 10).

Lila's chance arrival in Gilead is the key event in the novel: alone, after years of drifting, taking up menial jobs, including a short-lived engagement at a brothel, Lila makes her "home" in "a little house sitting a way off by a cluster of cottonwood trees, a sort of cabin someone had built and abandoned along with the fields around it" (Robinson 15), surviving by fishing, foraging and doing house chores in the town. The deserted shack might be a type of dwelling, humble as it is, where Lila sees "the poetics of space" (Bachelard 4) and accepts it as "a center of concentrated solitude" (Bachelard 32). This hut has the interliterary connection of recurring images with Housekeeping as Sylvie and Ruth also end up in an abandoned cabin in the woods. However, in Lila, the shack is an important space of liminal domesticity, encoding the unconventional nature of the dwelling and her lifestyle: "She had the likeness of a life, because she was all alone in it. She had the likeness of a house, with walls and a roof and a door that kept nothing in and nothing out." (Robinson 68). Her unusual temporary "home" in the "wild", in the natural world, allows her to establish a link with nature as the domestic space and the natural world intersect. Also, this abode introduces the focus of the novel, which is the troublesome adaptation of the heroine to the husband's house and the town. 
Prior to her arrival to Gilead, Lila seeks, albeit hesitantly, companionship, kindness and intimacy, evident in her frequent attempts to experience "home" and the related feelings at least vicariously: "It was probably loneliness that made her walk the mile or so into town every few days just to look at the houses and stores and the flower gardens" (Robinson 27). The same desire for "home" emerges in her recollections of Doll and the time in Tammany when she "sometimes would walk out at night, because then you can see into people's houses" (Robinson 196). This inspection of other people's homes connotes her marginality to domestic experience, indicative also of the drifter evaluation of houses. These family houses signify normality, stability, and conventional and normative living standards. But, as a vagabond, Lila is far from a traditional family person, and her character seems also to contribute to the debunking of the previously male-centered rendering of a transient. In Linda McDowell's words, "At one time, the stereotypical homeless person was a rathe $r$ romanticized version of the hobo or the tramp: a masculine figure who was unable to settle down and shoulder the responsibilities of home and work" (McDowell 90). Homeless for most of her life, Lila is anxious lest she succumbs to feelings of hope for the possibility of a different life, free from hardship and uncertainty, filled with safety and affection. She struggles with these divergent pulls, troubled by her unknown origins: "No point wondering about that cabin Doll took her from, or who it was that had kept her alive when she was newborn and helpless" (Robinson 36). New ways of thinking and living, including those related to domestic space, shape Lila's sense of belonging, formed around "[t]he good house, the kind old man" (Robinson 106). These adaptations to her new living arrangements also exert pressure on her to dismiss her previous living practice and attitude in favor of social conventions and expectations that at first make her feel banded and awkward: "She had never been at home in all the years of her life. She wouldn't know how to begin" (Robinson 107).

Since Lila has had very few experiences of domesticity, and those hardly harmonious, her sense of self cannot easily adapt to the mainstream norms of community life and household routines: "She wished sometimes he would tell her what to do, but he was always so careful of her. So she watched the other wives and did what they did, as well as she could figure it out" (Robinson 11). These words clearly imply the gendered construction of home but also suggest that she is on the margins of what Edward Relph designates as "existential insideness": "To be inside a place and to experience it as completely as we can" (Relph 55). Or, in more elaborate terms, Relph defines the sense of 
"insideness" as something "most people experience when they are at home and in their own town or region, when they know the place and its people and are known and accepted there" (Ibid.). Married and pregnant, Lila is drawn back in her thoughts and feelings to the reaches of her transient past, to "the wildness of things" (Robinson 106). ${ }^{4}$ Uneasy that she might lose her bond with nature in her new home because "in that quiet house she was afraid she might forget" (Robinson 106), Lila visits her old shack on the outskirts of Gilead, where she finds that it has been taken over by a homeless boy, maybe twelve years old. Since he is a transient like Lila used to be, she bonds with him, faster and easier than with Ames. She returns to town to get him some provisions as winter is imminent, but while she is gone, the boy, alarmed and desperate, leaves his "home" and goes back to his renegade existence. Lila returns to her home in town, heavy-hearted. A blizzard is coming so Lila and Ames shelter in their house, waiting for their baby to come. While they are excited that their child is about to become part of their world, they are unsettled over the homeless boy, out in the snowstorm, probably dying. Lila may have found her "home" and an "insideness" (cf. Relph) with her husband, but this episode can also be read against the background of Ames's old age and weak heart, raising the question of whether Lila will continue to make her home there after he dies or become homeless again. Such a possibility raises what was recognized by a critic as a common feature of Robinson's work - the understanding "that any true home-a space of complete comfort, stability, firm foundations-is an illusion" (Mariotti 24). Towards the end of the novel, while nursing their son and contemplating her domestic self against her homeless past, Lila struggles to accept the possibility of her happiness against "that old life": "Stepping back into the loneliness, a dreadful thing, like walking into cold water, waiting for the numbness to see in that was the body taking the care it could, so that what you knew you didn't have to feel" (Robinson 256). An increasing realization emerges that earlier spatial models and the limitations of "home" are to be reevaluated as these cannot constitute a foundation for a universal idealistic conceptualization of domestic space and womanhood: "We can be homeless-recognize and appreciate our essential instability,

\footnotetext{
${ }^{4}$ Lila's wary and withdrawn nature is also noted by reviewer Colm Tóibín who points out that "Lila has a strange, almost feral innocence." He further ascribes this trait to her past abandonment and inherent goodness which Robinson describes as "the tension between someone who seems lost in the world, a sort of waif, yet who carries a glow, [...] a striving for sanctity, the aura of someone destined by virtue of grace for another world" (22).
} 
foundationlessness - while still house-keeping, while still within the space of the home" (Mariotti 24).

The novel draws to its conclusion as Lila finds a way "home": her longing for "a real house" and a home is less a search for a site than a feeling of belonging in the sense of intimacy and comfort in her relationship with Ames. As Alex Engebretson suggests, the quest for home in Robinson's writing is realized in interpersonal terms and " $[t]$ he central drama of each of her novels is the slow, painstaking journey toward intimacy between two individuals" (13). The closing thoughts offer Lila's focalization on her family life, warding off her thoughts of leaving Gilead: "Well, for now there were geraniums in the windows, and an old man at the kitchen table telling his baby some rhyme he'd known forever, probably still wondering if he had managed to bring her along into that next life [...]." (Robinson 261). It is a "real house", Lila's real home, at least for the time being, developed around her accepting her sense of domesticity as a redemptive condition that gives her the advantage of contemplation and care, contrary to her previous transient and vulnerable life. Domesticity seems materially and symbolically encoded in Lila's gardening, but gardens, even geranium pots on windowsills, appear liminal to the house itself.

\section{Concluding Remarks}

Based on ideas of cultural and feminist spatial studies, this research has shown that the eponymous heroine of Robinson's novel Lila, an outsider and former transient, is forced to renegotiate the dominant notions of domesticity and womanhood. Her understanding of what constitutes her place of belonging resists conventional ideological constructions of home as the absolute place of nurture and well-being. Lila's history of displacement from her earliest childhood and later experience of deprivation and loneliness instilled in her not only a deepseated distrust of other people's ability to care for her, but also disbelief that she might actually deserve to have a home anywhere and in anyone's heart. This analysis has established that the protagonist's sense of self and identity is shaped by reservations about the space of home itself, triggered by loss, neglect and violence of her time when she was a toddler in the harsh workhouse where she was taken from by Doll. Consequently, Lila has no place that she can safely claim as home, no "place-called-home" (cf. Massey), and lives on the margins of society, exemplifying the opposition to typical (and gendered) classifications of home as a woman's place. This liminality seems to impart in her an enduring guardedness and drifter's inclination, also echoing the feminist geographers' conceptualizing of home as a locus of attachment, 
rejection and contestation. The paper's findings further elucidate how the protagonist is affected by her experience of the stable household and its material advantages during the year at the boardinghouse in Tammany where she likes attending school but does not challenge Doll's decision to leave the place without any apparent reason. Lila's reaction confirms that her sense of loyalty to her savior Doll is stronger than the comfort and certainty of the house, leading to the deduction that Lila's subsequent abandonment by her role model and care-giver Doll exacerbates Lila's sense of marginality and precarity in her adulthood. Moreover, this act of desertion contributes to her conflicted feelings of loneliness and yearning for intimacy, while also strengthening her inclination to the wild.

According to social and cultural geographies, home contributes to the shaping of a person's sense of self and functions in a dual manner, as a site and a spatial imaginary, where both home and identity are hinged on power relations (cf. Blunt and Dowling). This research determines that Lila's struggle to accept the customary expectations of domestic dynamics in the capacity of a Reverend's wife is also motivated by her care for her husband, and precludes her acceptance of the new arrangement based on the social construction of womanhood. This paper detects how her resistance to the gendered space of home manifests itself in her attachment to the shack in the woods outside the town, connoting her transitional dwelling and connection to the transient liberatory potential. To Lila, the shack appears like a house, with elements that make up a house: walls, roof, a door, but this analysis highlights the significance of how she sees that the door of the shack "kept nothing in and nothing out" (Robinson 68). Prior to her arrival to Gilead Lila has had very few experiences of domesticity, and those hardly harmonious, on account of her homelessness, so her attempts in the adaptation to the mainstream norms of community life and household routines signify the disputed configuration of home, framed by feminist geographers' theory of home as a locus of attachment, rejection and contestation. The contending forces of the character's transient homelessness of the past and her new domestic positioning reflect the understanding of home as a site where the material and imaginative areas and practices intertwine and where the process of inhabiting a space and of developing a sense of belonging to it are interlocked (cf. Blunt and Dowling). This analysis has led to the conclusion that Lila resists her new domestic arrangement and union with Ames lest she lose her connection with nature and hence her identity. For Lila, the process of creating a sense of place and belonging is conditioned by intimacy, and an important part of that intimacy is 
learning to take care of something of her own will, such as the flowers in Ames' garden when she first arrives in Gilead, and then, later, the potted geraniums on Ames' windowsills. Lila Illustrates both the construction of gendered subjectivity and the status of the domestic space while reminding us of the need for each individual to pursue and find "home" for themselves, in their own subjective understanding of what each person considers a "homeplace".

\section{Works Cited}

Acocella, Joan. "Lonesome Road. Marilynne Robinson returns to Gilead in her new novel." The New Yorker. Oct 6, 2014. https://www.newyorker.com/magazine/2014/10/06/lonesome-road. 14 April 2020.

Bachelard, Gaston. The Poetics of Space. [1958] Trans. Maria Jolas. 2nd ed. New York: The Orion, 1994.

Blunt, Alison and Robyn Dowling. Home. London: Routledge, 2007.

Engebretson, Alex. Understanding Marilynne Robinson. Columbia: U of South Carolina

$P$,

2017. EBSCOhost. search.ebscohost.com/login.aspx?direct=true \&db=nlebk\&AN=1503890\& site=eds-live. 10 January 2020.

Kakutani, Michiko. "Woman Caught in the Paradox of Being Adrift and on a Journey." New York Times. Sept. 28, 2014. https://www.nytimes.com/2014/09/29/arts/in-lila-marilynne-robinsongives-a-prequel-to-gilead.html. 9 January 2020.

Mariotti, Shannon L., and Joseph H. Lane. "Introduction. The Mystery of Experience: Marilynne Robinson's Political Theory." A Political Companion to Marilynne Robinson. Ed. S.L. Mariotti and J. H. Lane. Lexington: U P of Kentucky. $2016.21-17 . \quad$ EBSCOhost. search.ebscohost.com/login.aspx?direct=true \&db=nlebk\&AN=1215626\& site=eds-live. 10 January 2020.

Mariotti, Shannon. "The Housekeeper of Homelessness. The Democratic Ethos of Marilynne Robinson's Novels and Essays." A Political Companion to Marilynne Robinson. Ed. S.L. Mariotti and J. H. Lane. Lexington: U P of Kentucky. 2016. 21-55.

Massey, Doreen. Space, Place, and Gender. Minneapolis: U of Minnesota P, 1994.

McDowell, Linda. Gender, Identity and Place Understanding Feminist Geographies. Minneapolis: U of Minnesota P, 1999.

O'Rourke, Meghan. "A Moralist of the Midwest." New York Times. Oct. 24, 2004. https://www.nytimes.com/2004/10/24/magazine/a-moralist-ofthe-midwest.html. 9 January 2020.

Relph, Edward. Place and Placelessness. London: Pion, 1976.

Robinson, Marilynne. Lila. New York: Farrar, Straus \& Giroux, 2014. 
Rose, Gillian. Feminism and Geography. The Limits of Geographical Knowledge. Maiden, MA: Polity, 1993.

Sykes, Rachel. "Marilynne Robinson". The Routledge Companion to TwentyFirst Century Literary Fiction. Ed. Daniel O'Gorman and Robert Eaglestone. London: Routledge, 2019. 424-433.

Sykes, Rachel. The Quiet Contemporary American Novel. Manchester: Manchester U P, $2018 . \quad$ EBSCOhost. search.ebscohost.com/login.aspx?direct=true\&db=nlebk\&AN=1690384\& site=eds-live. 10 January 2020.

Tóibín, Colm. "Putting Religion in Its Place." London Review of Books 36.20 (2014): 19-23. https://www.Irb.co.uk/v36/n20/colm-toibin/puttingreligion-in-its-place. 10 December 2019.

\section{PONOVNO ODREĐENJE DOMA I BESKUĆNIŠTVA U ROMANU LILA MARILYNNE ROBINSON}

Posljednja desetljeća donijela su snažnija promišljanja doma, njegovog pojma, vrijednosti i značaja, i to sve više s pristupom proučavanja koji dom ne razmatra samo kao stvarni fizički prostor već i kao prostor predstavljanja i mjesto u pamćenju. Novija izučavanja razmatraju kućni prostor kao društveni konstrukt koji predstavlja pregovaranja i nadmetanja moći. Polazeći od koncepata iz kulturalne i feminističke geografije, ovaj članak se bavi analizom romana Lila Marilynne Robinson i njegovim shvaćanjem pripadanja i osamljivanja uz propitivanje koncepcije doma. Članak analizira dom kao orodnjeno mjesto i ponovno određenje ženskosti u otporu ka pomirenju sa životom kućanske dinamike u srcu Amerike koje Robinson voli označiti kao "srednje od zapada“. Drugim riječima, rad potvrđuje važnost da se predstavljanju doma i beskućništva u ovom romanu pristupa izučavanjem prostornosti iz rodnog očišta.

Ključne riječi: američki roman, dom, beskućništvo, osjet mjesta, pripadanje, rodni odnosi, ženski subjektivitet 